\title{
The Role of Competition Policy in the Promotion of Economic Growth
}

\author{
Lawrence J. White \\ Stern School of Business \\ New York University \\ Lwhite@stern.nyu.edu \\ Presented at the \\ Competition Policy Research Center \\ Fair Trade Commission of Japan's \\ International Symposium \\ on \\ "The Role of Competition Policy in the Promotion of Economic Growth" \\ Tokyo \\ March 7, 2008
}

Draft: March 30, 2008

\begin{abstract}
$\underline{\text { Abstract }}$
This essay discusses the role that competition policy can play in promoting economic growth. The essay begins by outlining the main components of modern antitrust policy. The essay then discusses the major aspects of an economy that contribute to economic growth and shows the ways that competition policy can favorably influence economic growth. Next the essay discusses "industrial policy", as a set of policies that are in contradiction to competition policy and describes the tensions between them. Finally, the paper discusses the role of economics and economists in the development of competition policy in the U.S. and highlights some major advances in U.S. competition policy (to which economics and economists have contributed), which have made competition policy more consonant with economic efficiency (and economic growth); in addition, some potential improvements that could promote the effectiveness of competition policy even further are proposed.
\end{abstract}

Keywords: Competition policy, antitrust, economic growth, industrial policy, regulation

JEL codes: K21, L40, L51, L52 


\title{
The Role of Competition Policy in the Promotion of Economic Growth
}

\author{
Lawrence J. White ${ }^{*}$ \\ Stern School of Business \\ New York University \\ Lwhite@stern.nyu.edu
}

\section{Introduction}

It is easy for competition policy ${ }^{1}$ enthusiasts (like myself) to get carried away and go overboard in extolling the merits of good competition policy. It is tempting to claim that good competition policy is the cure for everything that ails any economy.

It is tempting -- but it is wrong. Good competition policy clearly can be of substantial benefit to an economy. But it is not a "cure-all"; and to claim otherwise is to "over-sell" competition policy, which surely is not in the long-run interests of its advocates. At the same time, however, competition policy should not be "under-sold" either; it is surely more than just a minor adjunct to other policies that are in a government's tool bag.

This essay will address the role of competition policy in promoting economic growth. Competition policy clearly does have a role -- an important role, in my view -- to play. However, in the spirit of the "middle path" that I have just expounded, I will try neither to over-sell nor to undersell the importance of that role.

The remainder of this essay will proceed as follows: Section II provides a brief overview of the important components of a sensible competition policy. Section III will sketch the range of policies that contribute to economic growth; this review will clarify the contribution that competition policy can make through its effects in helping promote other policies, as well as its direct effects in

\footnotetext{
* The author was the Chief Economist in the Antitrust Division of the U.S. Department of Justice, 1982-1983.

${ }^{1}$ Throughout this paper the terms "competition policy" and "antitrust policy" (which is the term that is more common in American usage) will be used interchangeably.
} 
promoting competition and thereby promoting economic efficiency. Section IV then addresses the question of "industrial policy" and its juxtaposition with competition policy. Section V will review the growing importance of economics and economists for competition policy in the U.S. and will highlight some recent (in the past few decades) advances in U.S. competition policy to which economists have contributed and that have caused competition policy to be more in consonance with the goal of promoting economic efficiency and thereby contributing to economic growth; this section will also offer some suggestions for additional improvements that could promote the cause of economic efficiency (and economic growth) even further. Section VI will offer a brief conclusion.

Throughout this essay, I will be drawing on the experience of the United States in formulating and implementing its competition policy. Partly this is because the U.S. has the longest experience of any country in the world with respect to the formulation and implementation of competition policy; partly this is because the U.S. has hitherto tended to be a leader (among those countries with competition policies) in new developments in competition policy; ${ }^{2}$ and partly this is because I am most familiar with the policies of the U.S. Also, I will be emphasizing the perspective of economics with respect to these policies, since that too is the perspective with which I am most familiar.

\footnotetext{
${ }^{2}$ Two examples in this respect come readily to mind: the development of merger guidelines (and especially the market delineation paradigm for antitrust analysis of mergers -- see the discussion in Section V below), and the development of "corporate leniency" policies that encourage cartel participants to break ranks and reveal the existence of the cartel to enforcement authorities.
} 


\section{What is Competition Policy?}

Competition policy can be defined generally as a set of policies and instruments that are intended to encourage competition in markets and to encourage the allocative efficiency that generally accompanies competition. Competition policy broadly encompasses efforts at:

- Preventing cartels or other joint efforts at price-fixing (or market allocation, or agreements on product attributes);

- Preventing mergers where the consequences would be a significant lessening of competition (or a strengthening of whatever market power may already be present); and

- Preventing unilateral actions by a seller where the consequence would be a significant enhancement of the seller's market power. ${ }^{3}$

In the U.S., these policies are enunciated in the Sherman Act of 1890, the Clayton Act of 1914, and the Federal Trade Commission Act of 1914 (and subsequent amendments to these Acts) and in a rich history of clarifying court decisions. ${ }^{4}$

It should be readily admitted that not all policies that have the descriptor "competition policy" are in fact competition-enhancing and/or efficiency-enhancing. In the U.S., for example, at various times populism and anti-bigness have been important themes of American "antitrust" policy, which have led to legislation and legal decisions that favored the preservation of small businesses for their own sake rather than focusing on the competition-efficiency nexus. ${ }^{5}$ Misguided concerns about

${ }^{3}$ Although competition policy is usually framed in terms of actions by and market power created or enhanced by one or more sellers, the same principles can be applied to actions by buyers.

${ }^{4}$ Overviews of the U.S. antitrust laws and court cases can be found in various antitrust law texts, such as Areeda and Hovenkamp (2004), Areeda, Kaplow, and Edlin (2004), Sullivan and Hovenkamp (1999), Sullivan and Grimes (2006), and Hovenkamp (1999a, 1999b, 2005) and in economics writings, such as Kwoka and White (1989, 1994, 1999, 2004, 2009) and Buccirossi (2007).

${ }^{5}$ The Robinson-Patman Act of 1936 (which was an amendment to the Clayton Act and was intended to inhibit manufacturer price discrimination that would favor large retailers and chains; it is still intact) and the Miller-Tydings Act of 1937 (which authorized states to legalize resale price 
vertical mergers and vertical restraints (such as tying, exclusive dealing, territorial allocation, and resale price maintenance) have impeded effective competition as well as efficiency. ${ }^{6}$

Nevertheless, most modern interpretations of competition policy would describe it in terms of the three broad policy thrusts mentioned above.

maintenance, at the behest of small retailers -- especially pharmacists -- who feared the lower prices of retail chains; it was repealed in 1975) are notable pieces of "antitrust" legislation that were expressly designed to favor small business. The decisions by the U.S. Department of Justice (DOJ) and the Federal Trade Commission (FTC) to block mergers in the 1960s, supported by a string of Supreme Court decisions -- most notably Brown Shoe Co., Inc. v. U.S., 370 U.S. 294 (1962) -- were clearly aimed more at bigness itself than at realistic concerns about effective competition.

${ }^{6}$ See, for example, White (1989) and Kwoka and White (1989, 1994, 1999, 2004, and 2009). 


\section{Policies That Promote Economic Growth}

There are an array of policies that can contribute to the promotion of economic growth in a country. ${ }^{7}$ As will be seen, competition policy is both a direct contributor in its own right, as well as an indirect contributor through the enhancement of other policies. In considering this array of policies, the best perspective is to consider that there are tradeoffs among them.

\section{A. Encouraging saving.}

Higher rates of saving -- the setting aside of resources that otherwise could have been consumed and that are instead devoted to investment -- clearly are a contributor (cet. par.) to economic growth. Among the things that can encourage saving are sensible tax policies, efficient financial markets (which competition policy can help support), a legal system that embodies property rights (so that savers can be assured that they will retain the fruits of their saving) and a general "rule of law" (so that savers more generally have reasonable levels of certainty as to the consequences of their actions), and favorable cultural influences.

B. Encouraging efficient deployment of savings: investment.

Efficient investment will yield greater output payoffs and thus enhance economic growth. Among the things that can encourage more efficient investments are sensible tax policies, sensible regulatory policies, property rights and the rule of law, efficient financial markets, and efficient markets generally (so that investors receive efficient price signals to guide their investments). Competition policy clearly can contribute to the last two of these influences.

C. Encouraging productivity improvements and innovation.

Since most of economic growth appears to come from something more than just the accumulation of greater amounts of labor and capital in production processes, ${ }^{8}$ encouraging

${ }^{7}$ The literature on the components of economic growth is vast and cannot be surveyed here. Some interesting evidence can be found, for example, in King and Levine (1993a, 1993b), La Porta et al. (1997, 1998), and Levine (1997, 1998, 1999).

${ }^{8}$ See, for example, Solow $(1957,1988)$. 
productivity improvements and innovation is important for growth. Among the things that can encourage productivity improvements and innovation are sensible tax policies, an effective intellectual property rights regime (so that innovators can appropriate at least some of the gains from their innovation), policies to encourage saving and investment (since investments in new capital goods are often the vehicle for productivity improvements), policies to encourage education and investments in human capital, and efficient markets (which will send the correct price signals so as to encourage efficient innovation). Again, competition policy can play a role with respect to this last element.

What about Schumpeter? It is clear that Joseph Schumpeter's notion of "creative destruction" -- major "paradigm changing" innovations that disrupt and destroy existing markets and in their stead create new markets -- has a role to play in economic growth. The revolutionary improvements in data processing, electronics, and telecommunications over the past few decades are testaments to this power. But the conditions that Schumpeter thought were necessary for such improvements -- large enterprises (so as to take advantage of economies of scale in research and development and in the exploitation of the advances emerging from the $R \& D$ ) that also had monopoly market positions (so as to be able to appropriate the fruits of the $R \& D$ process) -- do not appear to be required and indeed may stifle innovation rather than encourage it. ${ }^{9}$ Although an economy filled solely with atomistic competitors would likely also not be ideal for encouraging innovation -- some scale is required, and surely the distinctiveness that goes with branding (as well as the property rights that accompany patents, copyright, and trademarks) is also important -- there is a broad intermediate range of competitive market structures that should be conducive to innovation.

${ }^{9}$ In Schumpeter's defense, he saw large enterprises as capable of such wide-ranging innovation that he envisioned any monopoly position that an enterprise might gain as largely temporary, since innovations by enterprises outside of any market were likely to allow the innovators to enter those markets and thus thwart any existing monopoly (but then -- temporarily --create a new monopoly, which would then be undone by further outside innovation, etc.). See Schumpeter (1950). 
Also, it appears that the incremental improvements that often follow a major breakthrough may be at least as important in the measurement of overall productivity improvements. ${ }^{10}$

D. Encourage entrepreneurship.

In addition to product and process innovation as a technological phenomenon, the encouragement of entrepreneurship -- especially the entrepreneurship that accompanies innovation -is another contributor to economic growth. Among the things that enhance entrepreneurship are favorable cultural conditions, sensible tax policies, educational policies, the rule of law, and competitive markets generally (again, so that entrepreneurs are responding to the right price signals). Competition policy can clearly contribute to this last element.

\section{E. Encourage efficient markets.}

Efficient markets have been mentioned repeatedly as supporting the other contributors to economic growth. But efficient markets deserve a mention also as a direct contributor, since an economic system with the correct price signals will be one in which firms are encouraged to make decisions not only with respect to static efficiency but also with respect to the investment and R\&D decisions that lead to economic growth. Openness to international trade is one important contributor to efficient markets. And competition policy, by directly encouraging efficient (competitive) markets and also by being a "cultural" influence that encourages other government policies (such as regulatory policies) to be oriented toward markets and competitive outcomes, clearly has an important role to play in this respect. ${ }^{11}$

${ }^{10}$ For overviews of the "point and counter-point" with respect to the Schumpeterian arguments, see, for example, Scherer (1984), Cohen and Levin (1989), Scherer and Ross (1990, ch. 17), and Cohen (1995).

${ }^{11}$ In the U.S., for example, for over 30 years the DOJ and the FTC have had "competitive advocacy" programs, whereby they "lobby" other federal agencies and the 50 state governments to pursue regulatory policies that are more oriented toward markets and competitive outcomes. 


\section{What about "Industrial Policy"?}

"Industrial policy" often stands in juxtaposition with competition policy as the means by which governments can promote economic growth. Although industrial policy, especially in the U.S., was more actively debated during the 1970s and 1980s, it has not disappeared from the policy debate. ${ }^{12}$ Accordingly, some discussion of industrial policy is worthwhile. ${ }^{13}$

\section{A. What is industrial policy?}

To start, unlike competition policy, there is no standard definition or general agreement on the meaning of the term "industrial policy". Consider the following:

-- "Industrial policy refers to a set of measures taken by a government and aiming at influencing a country's performance towards a desired objective." (Pitelis 2006, p. 435)

-- "Industrial policy means the initiation and coordination of governmental activities to leverage upward the productivity and competitiveness of the whole economy and of particular industries in it." (Johnson 1984, p. 8)

-- '"Industrial policy' refers to all policies designed to affect the allocation of resources between and within sectors of the economy." (Lawrence 1986, p.126)

-- "... the term industrial policy indicates the relationship between business and government on a microeconomic level..." (Wachter and Wachter 1981, p. 1)

-- "Industrial policies are concerned with promoting industrial growth and efficiency." (OECD 1975, p. 7)

At these broad levels of generalities, every country has an "industrial policy". After all, governments in all countries have policies that affect the relationships between business and government, that affect the allocation of resources, and that have some objective, often couched in

\footnotetext{
${ }^{12}$ See, for example, Bianchi and Labory (2006).

${ }^{13}$ Further discussion can be found in White (2008a).
} 
terms of efficiency, productivity, and/or growth.

Now consider the following:

-- "In current use, the term 'industrial policy' denotes the promotion of specific industrial sectors rather than industrialization overall... Industrial policies are direct, micro, and selective; they are an attempt by government to influence the decision making of companies or to alter market signals; thus they are discriminating... Industrial policy has sometimes sought to support the losers, delaying or retarding their decline; in other cases the goal is to succor or catalyze maturing sectors or to stimulate advancing sectors." (Driscoll and Behrman 1984, p. 5)

This last definition comes closest to the general sense of "industrial policy", of which a condensed version is often expressed as "the government's picking winners and losers". But in the discussion that follows I make references to both the broader descriptions of industrial policy above and the narrower version just discussed.

B. The tensions between competition policy and industrial policy.

Industrial policy -- whether considered as the general governmental intervention in markets or as the specific "picking winners and losers" -- is basically at odds with competition policy. The latter has a markets orientation; the former does not.

The U.S. experience is instructive. Though the U.S. does not have a formal industrial policy in the sense of Behrman and Driscoll (1984), it certainly has a patchwork of intervention policies that would satisfy the Lawrence (1986) description. First there are the formal exemptions from the reach of the antitrust laws, including: ${ }^{14}$

- Agricultural and fishing cooperatives;

- Insurance;

- Export associations;

- Cooperative research joint ventures;

\footnotetext{
${ }^{14}$ This list can be found in AMC (2007).
} 
- Newspaper joint ventures;

- Ocean shipping conferences; and

- Professional baseball.

Next, there are a range of federal government actions that are at odds with the spirit of the antitrust laws, including:

- International trade restrictions (tariffs, quotas, subsidies, etc.);

- International investment restrictions;

- "Buy American" policies for government procurement (including, but not limited to, defense procurement);

- Government technological development programs that favor U.S.-based companies;

- Agricultural policies that subsidize and protect domestic farmers and that inhibit competition; and

- Tax and subsidy policies that favor some industries over others. ${ }^{15}$

Further, although less prevalent today than a few decades ago, there are formal federal regulatory regimes for transportation industries (air, rail, truck, pipelines), telecommunications (telephony and broadcasting), energy (electricity, natural gas), and finance (banking and securities). In such instances, antitrust policy is superseded by a broader and more vague "public interest" standard that often justifies anticompetitive regulatory restrictions.

Finally, the 50 states have often (although, again, less today than a few decades ago) placed anticompetitive restrictions on a number of industries, including:

- Banking;

- Intra-state trucking;

- Intra-state long-distance telephone service;

${ }^{15}$ A current example of this type of policy, with all of its inefficient consequences, is U.S. policy toward corn-based ethanol production as a substitute for petroleum as a motor fuel. 
- Insurance;

- Licensing of occupations and professions;

- Local taxicab service; and

- Health care.

There are, of course, legitimate "market failure" arguments for modifying market outcomes. These include problems of significant spillovers or externalities (positive or negative) and significant information asymmetry problems. Competition policy should not be expected to encompass remedies for these types of problems, so additional policies are warranted. However, "industrial policy" interventions -- though their supporters sometimes invoke the rhetoric of externalities or information asymmetries -- are usually (at base) primarily about rent-seeking and income redistribution. And even when policies truly are aimed at dealing with externalities (such as environmental pollution problems), rent-seeking often inhibits the development of programs that would encourage competition and enhance efficiency. ${ }^{16}$ Despite their recent popularity, "cap and trade" programs (which do encourage efficiency and competition) are still the exception rather than the rule for the U.S.

In the 1970s and 1980s, as economic growth slowed (and Japan's economic strength seemed based on its adoption of a formal industrial policy ${ }^{17}$ ), the U.S. seriously debated the possibility of embracing a more formal version of industrial policy (as compared with the patchwork of policies described above)-- but declined the opportunity. Indeed, this was a period of significant movement in the opposite direction: the economic deregulation of industries that had been subject to the formal regulatory regimes mentioned above. ${ }^{18}$ As a consequence, the domain of markets and of the

${ }^{16}$ See, for example, Ackerman and Hassler (1981).

${ }^{17}$ See, for example, Behrman (1984), Johnson (1982, 1984), and McCraw (1986).

18 See, for example, Joskow and Rose (1989), Joskow and Noll (1994), and Winston (1993, 1998). 
application of the antitrust laws is wider today than was true of the 1930s or even of the early 1970s. Nevertheless, the tensions remain between antitrust policy and that patchwork of intervention that continues to characterize U.S. (industrial) policy. 


\section{$\underline{\text { V. Advances in Competition Policy }}$}

Competition policy should not be static, and in the U.S. it has not been static. In the past two to three decades, especially, American antitrust policy has accommodated new economics thinking and new forms of analysis -- much for the good. This section will first summarize the ways in which economics and economists have influenced U.S. antitrust policy. Next, three specific important advances in (relatively) recent antitrust policy that have been greatly influenced by economics will be discussed. Finally, four areas that still need improvements (and to which economics could likely contribute) will be outlined. ${ }^{19}$

\section{A. The influence of economics and economists.}

The influence of economics and economists on antitrust in the U.S. has occurred through three broad channels.

1. The development of microeconomics thought. The economics foundation for antitrust policy has been microeconomics generally and industrial organization (IO) economics more specifically. IO economics has its origins in work by Edward Mason and his colleagues and students in the late 1930s and early 1940s in developing the structure-conduct-performance (S-C-P) paradigm as a theoretical proposition and then providing empirical tests of the theory. ${ }^{20}$ Data and monographs from the Temporary National Economic Committee (TNEC) in the late 1930s helped in this endeavor.

Over the following few decades the S-C-P tradition was strengthened by further theoretical and empirical developments, and it began to influence antitrust policy. In the 1950s, however, a second strand of IO economics developed at the University of Chicago, under the leadership of Aaron Director. ${ }^{21}$ This approach was more skeptical of the S-C-P paradigm, more sympathetic to

\footnotetext{
${ }^{19}$ More detail on all of the topics in this section can be found in White (2008b).

${ }^{20}$ See Shepherd (2007) and De Jong and Shepherd (2007).

${ }^{21}$ See Peltzman $(2005,2007)$.
} 
vertical restraints, and more supportive of unhindered market outcomes.

In recent decades both strands of IO thinking have clearly influenced U.S. antitrust policy. Some specific influences will be discussed in Part B below.

2. Direct employment of economists by the enforcement agencies. Economists have been directly employed by the enforcement agencies in the U.S. for over 100 years. The U.S. Bureau of Corporations, which was established in 1903 and which had economists on its staff, provided valuable research support for some of the early and important antitrust victories by the DOJ. When the FTC was created in 1914, its Economic Department (which eventually became today's Bureau of Economics (BE)) inherited the Bureau of Corporation's research and investigative role, as well as absorbing its specific office accommodations and personnel (including economists).

Until the 1960s, however, economists at both agencies were largely in roles of simple litigation support, with few opportunities to participate in the development of case theories and the formulation of policy. But in the 1960s the tide began to turn. At the DOJ, Donald Turner (the Assistant Attorney General for Antitrust in the mid 1960s, who had a Ph.D. in economics as well as a law degree) established the position of Special Economic Assistant to the Assistant Attorney General and attracted a series of young IO economists to serve one-year terms in the position. ${ }^{22}$ At the FTC, the BE was able to attract Ph.D.-trained IO economists as Bureau Directors. ${ }^{23}$ But little was done to strengthen the quality and authority of the permanent economics staff at either agency. Reviews of both agencies at the end of the 1960s commented unfavorably on the quality and role of the economics staffs at the agencies. ${ }^{24}$

Beginning in the 1970s, however, concerted efforts were made to improve the quality of the

\footnotetext{
${ }^{22}$ See Williamson (2003).

${ }^{23}$ See Mueller (2004).

${ }^{24}$ See ABA (1968), Posner (1971a), and Green (1972).
} 
economists at both agencies, as well as to increase their numbers. These efforts have continued to the present time. As of early 2008, the DOJ has 60 Ph.D.-level economists, headed by a Deputy Assistant Attorney General who is usually a leading academic IO economist and who typically serves for two years in the position. At the FTC, the BE is staffed by 70 Ph.D.-level economists (although they spend about a quarter of their time on consumer protection issues), and the Bureau Director is usually a leading academic IO economist who spends about two years in the position.

\section{Economists' participation in and writing about specific antitrust cases.}

The participation of economists in antitrust cases extends back at least to the second decade of the twentieth century, when the DOJ used an economist (who had been a Deputy Commissioner in the Bureau of Corporations) as an expert witness at trial in its case against U.S. Steel. ${ }^{25}$ But the use of economists was not widespread over the next few decades, nor were economists apparently especially interested in writing about antitrust cases.

With the development of the IO paradigm in the late 1930s and the 1940s, however, IO economists began to take an interest in major antitrust cases, at least as outside observers, and to write about them. An antitrust symposium in the May 1949 "Papers and Proceedings" issue of the American Economic Review provides an example of this newly developed interest. ${ }^{26}$ An important instance of direct participation occurred when Carl Kaysen, in 1950 as a Ph.D. student of Edward Mason's, was appointed as a law clerk by Federal District Court Judge Charles Wyzanski, to provide economic counseling to Judge Wyzanski in the DOJ's monopolization trial of the United Shoe Machinery Company. Kaysen served for two years in that position and wrote a lengthy report for Judge Wyzanski, which subsequently became Kaysen's Ph.D. dissertation and a book-length

\footnotetext{
${ }^{25}$ The Supreme Court ultimately decided that case in favor of U.S. Steel and cited disparagingly the testimony that had been offered at trial by that economist. See U.S. v. United States Steel Corp., 223 F. Rep. 55, 251 U.S. 417 (1920).

${ }^{26}$ See Adelman (1949), Nicholls (1949), and Nicols (1949).
} 
monograph. ${ }^{27}$

By the 1970s economists were actively participating in antitrust cases more frequently as consultants and as expert witnesses, and then writing about those cases. The $\underline{\mathrm{IBM}}^{28}$ and $\underline{\mathrm{AT} \& \mathrm{~T}}^{29}$ cases, which were large and lengthy DOJ cases with some accompanying private cases as well, provided fertile opportunities for such participation and subsequent writings, but other suits and investigations also proved sufficiently interesting to yield publications. ${ }^{30}$ Since the 1970s economists' participation in antitrust litigation has become substantially more frequent ${ }^{31}$-- rare is the major antitrust case today that does not have one or more economists engaged on both sides -- and articles reflecting that participation also continue to appear. ${ }^{32}$

B. Important advances in U.S. antitrust policy.

There are three ${ }^{33}$ areas of U.S. antitrust policy where economists' achievements in helping

27 See Kaysen (1956). The case was U.S. v. United Shoe Machinery Corp., 110 F. Supp. 295 (1953), 347 U.S. 521 (1954).

${ }^{28}$ Discussion of this case, which was filed by the DOJ in 1969 and was dropped in 1982, can be found, for example, in Fisher et al. (1983), DeLamarter (1986), Houthakker (1999), and Brock (1989).

${ }^{29}$ The Case was filed by the DOJ in 1974 and was settled with a consent decree in 1982 on terms that were highly favorable to the basic goals of the DOJ. Discussion of the case can be found, for example, Evans (1983) and Noll and Owen (1994).

${ }^{30}$ White (2008b) provides an array of examples.

${ }^{31}$ See, for example, Kovacic (1992), FTC (2003), and Barnett (2007).

${ }^{32}$ See, for example, Kwoka and White (1989, 1994, 1999, 2004, 2009).

33 There is a fourth area in which U.S. antitrust policy has changed for the better: strategic leniency for the first member of a price-fixing cartel or agreement that comes forward with sufficient evidence to convict the other members. Though the DOJ had a policy of corporate leniency that was initiated in 1978, it applied only if the DOJ had not yet opened an investigation. Since a potential confessor often would not know if an investigation had been opened, this uncertainty discouraged confessions. In 1993 the DOJ revised the policy so that a confessor with important knowledge could still receive leniency even if an investigation had been opened. That clarification, plus the announcement itself, which freshly promoted the availability of leniency, converted it into an 
bring changes are especially noteworthy: merger analysis, vertical relationships and restraints, and predatory pricing. ${ }^{34}$

1. Merger analysis. Almost all of modern antitrust merger analysis takes as its starting point the DOJ-FTC Horizontal Merger Guidelines. The Guidelines -- first published in $1982^{35}$ and subsequently revised in 1987, 1992, and 1997 -- were strongly influenced by economics thinking and by the inputs of economists at the agencies.

The Guidelines establish two approaches under which a merger might be deemed to have anticompetitive consequences: "coordinated effects" and "unilateral effects".

a. Coordinated effects. This is a direct application of the S-C-P model, with some special emphases derived from the writings of George Stigler. ${ }^{36}$ The primary concern is that the oligopolistic sellers in the market, post-merger, will be able better to coordinate their behavior implicitly so as to achieve higher prices (or to effect other changes in conduct variables) and higher profits. Seller concentration is measured by the Herfindahl-Hirschman Index (HHI) and occupies center stage (as it does in the S-C-P model) for at least two reasons: First, seller concentration is the

important tool. Although economists were surely supportive of the strategy -- after all, it is consistent with the basic structure of the "prisoner's dilemma" approach to understanding incentives in a cartel-like situation -- it is unclear that economics and economists were as directly involved in the change as is the case for the three advances discussed in the text. For further discussion of the leniency program, see White (2003), Harrington (2006), and Wils (2007).

${ }^{34}$ In addition to the major achievements in the text, "honorable mention" for antitrust economists might include: (a) being early advocates of the economic deregulation of the securities and banking markets, transportation markets, telecommunications markets, and energy markets; (b) being major advocates for larger fines and the continuation of treble damages in private antitrust suits as instruments for deterrence; and (c) being major advocates for the repeal of the Robinson-Patman Act.

${ }^{35}$ An earlier set of DOJ Guidelines were published in 1968 but proved unsatisfactory and were largely scrapped when the 1982 Guidelines were adopted.

${ }^{36}$ See, especially, Stigler (1964). 
most readily measured structural attribute; and, second, the immediate effect of any horizontal merger is to increase seller concentration.

The Guidelines also bring into the analysis the other important features of the S-C-P paradigm: conditions of entry; the buyer side of the market; the nature and complexity of the product; the transparency of price and of other market information; and the antitrust history of the sellers in the market.

A particular problem of implementing merger enforcement prior to 1982 had been the issue of defining the relevant product and geographic markets. The S-C-P model is silent on this issue; the model simply assumes that an appropriate market has been specified, so that the market shares of the leading sellers provide a meaningful indication of the likelihood that the sellers (post-merger) will collectively exercise market power. The model provides no guidance with respect to delineating the market itself.

The Guidelines address this problem in the following way: ${ }^{37}$ A relevant market is a product or group of products that are sold by a group of sellers who, if they acted in concert (i.e., if they acted as a "hypothetical monopolist"), could achieve a "small but significant and nontransitory increase in price" (SSNIP); that SSNIP is designated in the Guidelines as 5\% for one year. This "SSNIP test" is equivalent to defining a relevant market as one in which market power can be exercised (or one in which market power can be enhanced). The smallest group of sellers that satisfy the SSNIP test is usually designated as the relevant market, although sometimes a larger market is chosen. These principles apply equally validly to the delineation of product markets and of geographic markets. In essence, the determining factor is whether a sufficient number of buyers would switch away to other sellers -- sellers of other goods and/or sellers that are located in other geographic areas -- so as to thwart the price increase.

The logic of the SSNIP test approach follows from the goal of preventing mergers that could

\footnotetext{
${ }^{37}$ As Werden (2003) has pointed out, this approach was first proposed by Adelman (1959).
} 
create or enhance market power. The SSNIP test identifies the smallest group of sellers that could exercise such power. ${ }^{38}$

This market definition paradigm has proved enduring, and merger enforcement authorities in other countries have adopted similar approaches.

b. Unilateral effects. The 1992 revision to the Merger Guidelines added "unilateral effects" as a second area of concern with respect to the antitrust analysis of mergers. Under this approach, the worry would be that a significant post-merger price increase could occur solely because of the actions of the merged entity, without the need for implicit coordination among the other (nonmerging) firms. This unilateral increase could occur if the two merging firms produced products that were moderately close substitutes for each other -- but not perfect substitutes -- and a significant number of the customers of one or both of the firms had as their runner-up choice the products of the merger partner. If the products of all other firms were distant enough "third choices" for these customers, then the merged entity could well find a general price increase to be worthwhile -- and the price increase would be even more likely if the merged firm could identify and target these "trapped" customers and thereby practice selective price discrimination against them. ${ }^{39}$

The anticompetitive effects of this type of merger do not arise because of cooperation or collusion among the firms that are situated alongside the merged entity in this differentiated market. Instead, the competitive harm occurs because the merged firm is better able to internalize the

${ }^{38}$ With one exception, the market definition paradigm focuses on sellers, since it is sellers that can exercise market power. That exception arises when a group of sellers may be able to practice price discrimination and raise prices significantly toward an identifiable group of buyers (who may be identified by, say, a specific geographic area or a specific business function). In such instances, that group of buyers may also be considered to be a relevant market.

${ }^{39}$ Unilateral effects could also occur if a dominant firm merged with one of its rivals, even in a homogeneous goods industry; see Stigler (1965). The post-merger concentration level and the merger-induced change in concentration from such a merger would probably trigger enforcement action in any event; but, to be on the safe side, the Guidelines also indicate that any merger involving a firm that has a market share of $35 \%$ or higher will receive special scrutiny. 
benefits of a price increase. For this analysis, the issues of market definition and of market shares are largely irrelevant; what matters is the extent to which customers have the two merging firms as their first and second choices and also the extent to which all other firms are distant third choices.

2. Vertical relationships and restraints.

The "Harvard" IO tradition that produced the S-C-P paradigm was (at least prior to the 1970s) largely hostile toward vertical relationships (including vertical mergers between a supplier and a customer) and vertical restraints, such as tying, bundling, exclusive dealing, requirements contracts, full-line forcing, territorial restraints, and resale price maintenance (RPM). ${ }^{40}$ This approach saw these vertical relationships and restrictions either as manifestations of market power or as instruments for the enhancement of the exercise of market power. ${ }^{41}$

The "Chicago" IO tradition, however, by the late 1950s was offering an alternative and far more benign view of these vertical relationships and restraints. Although acknowledging that they could sometimes be used for the purposes of cartel formation, the Chicago-oriented writers instead emphasized the efficiency-enhancing aspects of these practices. ${ }^{42}$

Consistent with the harsh "Harvard" view, the antitrust enforcement agencies and the

${ }^{40}$ See, for example Kaysen and Turner (1959), which had a generally negative view of virtually everything vertical.

${ }^{41}$ At least part of the reason for many economists' harsh view of RPM was the experience of the 1930s, when small retailers (and especially pharmacists) lobbied politically for protection against "unfair" competition from large chain stores. One legislative reaction that has already been noted above was the Robinson-Patman Act of 1936, which strengthened the Clayton Act's prohibitions on price discrimination; the small retailers alleged that the chain stores were unfairly extracting discounts from manufacturers (and thus benefiting from favorable price discrimination) that were unavailable to smaller retailers. Another response -- the Miller-Tydings Act of 1937 -- authorized the states to legalize RPM (which also went by the phrase "fair trade"), so that the small retailers could convince manufacturers to impose RPM and thus force the large chain stores to sell at the same retail prices as the smaller retailers. The Miller-Tydings Act was repealed in 1975.

42 See, for example, Bowman (1955, 1957, 1973), Telser (1960), Burstein (1960a, 1960b), Marvel (1982, 1985), and Marvel and McCafferty (1984, 1985, 1986). 
Supreme Court (in its antitrust legal decisions) prior to the mid 1970s were generally hostile toward vertical mergers and vertical restraints. From the mid 1970s onward, however, the enforcement agencies and the Supreme Court moved to a far more benign view of these practices -- recognizing potential anticompetitive possibilities but also recognizing the efficiency-enhancing possibilities. ${ }^{43}$ As of early 2008, the enforcement agencies are far more cautious in their choice of cases for prosecution, and the Supreme Court has declared that almost all vertical restraints should be judged under a "rule of reason" approach, where potential benefits are weighed against potential anticompetitive effects, ${ }^{44}$ rather than under a "per se" approach, where a practice is automatically condemned and the plaintiff need only show that the defendant did actually engage in the alleged practice. $^{45}$

3. Predatory pricing. Prior to the 1970s the antitrust authorities and the courts were unduly concerned about predatory pricing (as well as about price discrimination, where predation claims often were lurking). ${ }^{46}$ Common to enforcement actions and to judicial decisions were allegations of "pricing below cost", where "below cost" was either vaguely defined or was defined as below average costs -- which, for any multi-product firm, also meant using some arbitrary method of distributing joint costs across multiple products, such as using the relative sales revenues of the various products as the relative weights.

${ }^{43}$ An important turning point was the Supreme Court's decision in Continental T.V., Inc. v. GTE Sylvania, Inc., 433 U.S. 36 (1977). See Preston (1994) for a discussion.

44 The most recent case in this tradition is Leegin Creative Leather Products, Inc. v. PSKS, Inc., 127 S. Ct. 2705 (2007), in which the Supreme Court declared that RPM should be judged under a "rule of reason" standard.

45 As of early 2008, the one exception to this "rule of reason" approach is tying, where the Supreme Court has nominally kept a "per se" illegality standard. Even in this area, however, the Court has insisted that the plaintiff show that the defendant has market power before the "per se" condemnation will apply.

${ }^{46}$ For a critique, see Areeda and Turner (1975). 
Academic work to clarify predatory issues, and to cast doubt on the empirical frequency of predation, began at "Chicago" in the late 1950s. ${ }^{47}$ The paradigm of envisioning predation as an "investment" (an initial sacrifice) and then a subsequent recoupment period (higher prices permitting a profits return on the initial investment) became clear. As part of this paradigm, it also became clear that barriers to entry were a necessary component for success of this strategy; otherwise, entry would foil the predator's recoupment efforts; and to the extent that a would-be predator faced conditions of easy entry, attempted predation would not be a rational strategy. ${ }^{48}$

Building on this base, Areeda and Turner offered a powerful critique of existing legal thought and court decisions and offered a proposal that pricing at or above marginal cost (with average variable cost serving as a proxy for the usually unmeasurable marginal cost) should generally be considered as a "safe harbor" for firms that were being accused of engaging in predatory pricing. This proposal subsequently became known as the "Areeda-Turner rule". 49

Subsequent Supreme Court decisions were clearly influenced by the investment-plusrecoupment paradigm and the price-above-marginal-cost test. ${ }^{50}$

${ }^{47}$ See, for example, McGee (1958), Telser (1966), and Peltzman (2005).

${ }^{48}$ But, as is pointed out below, one or more attempts at predation, even if unsuccessful, might create a reputation for "aggressive" behavior by the price-cutter that would effectively discourage entry and/or would discipline rivals that might otherwise be inclined to be "mavericks".

${ }^{49}$ See Areeda and Turner (1975). Recall that Turner had a Ph.D. in economics as well as a law degree, so that this proposal can be considered as part of the contribution of economists toward improved antitrust policy. Elaborations on and extensions of the Areeda-Turner rule can be found in Scherer (1976), Williamson (1977), Baumol (1979), Joskow and Klevorick (1979), Ordover and Willig (1981), and Brodley and Hay (1981).

${ }^{50}$ See Matsushita Electric Industrial Corp., Ltd., et al. v. Zenith Radio Corp., et al., 475 U.S. 574 (1986); Brooke Group, Ltd. v. Brown \& Williamson Tobacco Corp., U.S. (1993); and most recently in Weyerhaeuser Co. v. Ross-Simmons Hardwood Lumber Co., Inc. 127 S. Ct. 1069 (2007). See also Elzinga (1999) and Burnett (1999) for discussions of the Matsushita and Brooke Group cases, respectively. 
At about the same time that economists in the antitrust area were clarifying notions of predation, economists in regulatory areas were writing about similar issues in the domain of price regulation and were nudging regulatory criteria and regulatory decisions away from the use of fully distributed costing methods (i.e., the process of allocating joint costs in some arbitrary fashion across multiple products) and instead toward the use of incremental costs. ${ }^{51}$

\section{Important improvements that are still needed in U.S. antitrust policy.}

Antitrust policy in the U.S. has certainly not reached "nirvana". Improvements are still needed, so as to bring antitrust policy even more closely in line with economic efficiency (and economic growth), and economists can surely contribute to the development of these improvements. There are at least four areas that are worth exploring:

1. Taking efficiencies into account in merger cases. The analytical basis for taking into account the tradeoffs between the potential efficiencies that a merger may offer and the loss of welfare that the heightened market power of the merger may create has been known for at least 40 years. $^{52}$ But efficiency improvements from a merger are easy to promise but may be difficult actually to deliver; and "unscrambling the eggs" of a merger a few years after it has been approved and the promised efficiencies have failed to arrive may be difficult or impossible. In addition, even the measurement of whether the promised efficiencies have actually appeared may be difficult.

Perhaps creative economics thinking can yield an incentive-compatible mechanism for inducing the merger proponents to provide their best estimate of the prospective efficiency gains from the proposed merger rather than providing just their wishful thinking or their fanciful efforts to offset the concerns of the enforcement agencies as to the adverse consequences of the possible exercise of market power.

\footnotetext{
${ }^{51}$ See, for example, Baumol (1968) and Baumol and Walton (1973).

${ }^{52}$ See Williamson (1968).
} 
2. A more nuanced approach to unilateral predatory behavior. As was discussed above, current antitrust decisions portray predation as a narrow strategy of an initial investment in belowmarginal-cost pricing followed by a recoupment period of higher prices and profits after the target firm departs from the market. Lost in this approach are strategic issues that extend beyond the immediate market and time period. For example, the would-be predator may not recoup its investment solely in this market and this time period. Suppose, for example, that by pricing its product at levels that are below marginal costs the firm gets a reputation for being overly aggressive. In this case, other firms might be more reluctant to enter during the attempted recoupment period; in essence, the predatory act itself might raise barriers to entry. Or this bout of predatory behavior might chasten or "discipline" firms that might otherwise become "maverick" price-cutters, thereby yielding higher long-run profits for the initiating firm. Or the predatory behavior in one (product or geographic) market may gain the firm a reputation for being aggressive that pays off in other markets through reduced entry or disciplined behavior in those other markets. ${ }^{53}$

Further, the narrow investment-plus-recoupment paradigm has proved difficult to apply to allegations of non-price predatory behavior (e.g., expansions of capacity or applications of various kinds of vertical restraints). ${ }^{54}$ And the issue of "bundled discounts" and whether they constitute a serious problem of predation is currently roiling antitrust discussion in the U.S. ${ }^{55}$

Clear economics thinking can surely help in this area. One promising line of thought that

53 See Brodley et al. (2000) for an elaboration on these strategic motives for pricing below marginal costs.

${ }^{54}$ See, for example, the discussion of the DOJ's failed case against American Airlines' alleged predatory behavior vis-a-vis start-up airlines -- U.S. v. AMR Corp., American Airlines, Inc., and American Eagle Holding Corp., 140 F. Supp. 2d 1141 (2001); 335 F.3d 1109 (2003) -- in Edlin and Farrell (2004).

${ }^{55}$ The case that precipitated this discussion is LePage's Inc. v. 3M, 324 F.3d 141 (2003); see Roberts (2009) for a discussion. It is noteworthy that the AMC (2007) Report devoted a relatively large amount of space to a discussion of this issue. 
should be pursued is the concept of "no economic sense": that a price or non-price action should be condemned as predatory (i.e., as anticompetitive) if it made no economic sense for the firm undertaking it unless the target firm disappeared from the market or would otherwise be disciplined. ${ }^{56}$

3. Market definition in monopolization cases. As was discussed above, for antitrust merger analysis the Merger Guidelines have embodied a robust paradigm for market definition. Unfortunately, the same cannot be said for monopolization cases. The crucial difference is that the antitrust analysis in merger cases is asking a prospective question -- will this merger create or enhance market power? -- so that the "SSNIP test" is the appropriate question. By contrast, in most monopolization cases the usual allegation is that the defendant already has market power, and the plaintiff wants the court to enjoin the defendant from acts (e.g., vertical restraints, or predatory pricing) that have allowed it to achieve or enhance that market power and/or enjoy the fruits of that market power. The defendant, of course, will deny that it has market power.

In this context, the SSNIP test cannot be used, because neither a truly competitive firm nor a true monopolist would find it worthwhile to raise its price from its current level (at which, presumably, it is already maximizing its profits). ${ }^{57}$ Prior to the 1980 s, accounting profitability measures would have been offered as support for the existence of market power. But substantial

${ }^{56}$ See, for example, Ordover and Willig $(1981,1999)$ and Werden (2006). It should be noted that this line of argument does not encompass the strategic reputation issues raised above.

57 To apply the SSNIP test would be to commit the "cellophane fallacy", named after the Supreme Court's analytical error in U.S. v. E.I. du Pont de Nemours \& Co., 118 F. Supp. 41 (1953), 351 U.S. 377 (1956). In that case, the DOJ alleged that du Pont was exercising market power in the cellophane market. In response, du Pont argued that it had no market power, because cellophane should properly be considered to be part of a much broader "flexible wrapping materials" market. Both the district court and the Supreme Court agreed with du Pont by -- in essence -- applying the SSNIP test: Those decisions concluded that du Pont did not possess market power since any attempt by it to raise the price of cellophane from existing levels would be thwarted (and thus would be unprofitable) by the switching of too many cellophane purchasers away to other flexible wrapping materials. 
doubt was subsequently cast on the use of accounting profitability measures as indicators of market power, ${ }^{58}$ and accounting measures of profitability have been used much more sparingly since then in antitrust cases. Perhaps creative thinking can yield a paradigm breakthrough in this area, as it did for mergers. $^{59}$

4. Determining the appropriate stringency for antitrust merger policy. Are the DOJ and the FTC drawing the right "lines" as to the decisions with regard to which mergers should be challenged and which should be approved? The general proposition -- based on the S-C-P paradigm -- that higher levels of seller concentration (and higher barriers to entry, etc.) increase the likelihood of the exercise of market power has strong empirical support. ${ }^{60}$ Nevertheless, it is clear that there are low levels of seller concentration at which the likelihoods of post-merger market power are quite low, and thus mergers among sellers would be harmless from a market power perspective and could create efficiencies -- and enhance economic growth -- and therefore should be approved; and there are high levels of seller concentration at which the likelihoods of the post-merger exercise (or enhancement) of market power are high and the prevention of mergers is consistent with the maintenance of overall market efficiency. But where should the appropriate line(s) be drawn, and is current merger policy at the right place?

The answers to these questions cannot be learned from examining the number of merger challenges per year, or examining the characteristics of the mergers that were challenged or of the mergers that were successfully challenged (since one can never know the "counter-factual" with respect to these mergers). But post-merger pricing studies of those mergers that are allowed to proceed -- especially the "close calls" -- should yield interesting information. These "close calls"

\footnotetext{
${ }^{58}$ See Benston (1982), Fisher et al. (1983), Fisher and McGowan (1983), and Fisher (1987).

${ }^{59}$ See White (2008c) for an elaboration on this problem and for some suggestions.

${ }^{60}$ See, for example, the survey and support in White (2006).
} 
would reasonably be represented by those mergers in which the merger partners are asked by the enforcement agencies for additional information ${ }^{61}$ but the mergers are eventually permitted to proceed. If the studies indicate that post-merger prices tend to increase significantly (cet. par.), then merger policy has been too lax and should be tightened (e.g., by lowering the HHI threshold at which a merger is likely to be challenged); if the studies indicate that post-merger prices do not rise, then merger policy may be too stringent (or might be "just right").

The DOJ and the FTC have the pre-merger data that would provide the baselines for these studies; they would be in the best positions to do the post-merger follow-up studies; and the economists in those agencies would surely be the most qualified personnel to do the statistical (econometric) work that would be necessary.

\footnotetext{
${ }^{61}$ In U.S. antitrust parlance, these are termed "second requests".
} 


\section{$\underline{\text { VI. Conclusion }}$}

It is clear that competition policy has an important role to play in the promotion of economic growth in a modern economy; but that role should neither over-sold not under-sold. Competition policy is not a magical cure-all for anything that ails an economic system; and there are clearly other important influences on the growth rate of a modern economy. Nevertheless, competition policy clearly does play an important role: directly, because of competition policy's emphasis on competitive markets and the efficiencies that flow therefrom, which surely encourage economic growth; and indirectly, because of the "markets" mindset that accompanies competition policy and because competition policy can encourage efficient financial markets, which in turn encourage the saving and efficient investment that themselves are important contributors to growth.

Good competition policy, unfortunately, is not an automatic choice for many economies. "Industrial policy", with its underlying foundation resting on the belief that the government can somehow better pick winners and losers than can markets, often stands counterpoised to the markets orientation of competition policy. Although the problems of significant externalities and asymmetric information often do justify extra-market interventions by government (since competition policy is simply not equipped to handle such "market failure" problems), the course of industrial policy usually goes far beyond such remedying interventions (although the proponents of industrial policy may sometimes wrap their arguments in the language of market failures). The powerful rent-seeking and political capture models of modern political economy are a better explanation for what really lies at the base of industrial policy. ${ }^{62}$ Competition policy and industrial policy are thus likely to continue to stand in tension with each other as modern economies develop and mature.

Good competition policy should not stay stagnant but should adapt as circumstances change and especially as economics thinking evolves. In the U.S. there has been a substantial history of the influence of economics and economists on antitrust policy, most of it for the good. Economics and

\footnotetext{
${ }^{62}$ See, for example, Posner (1971b, 1974), Stigler (1971), and Peltzman (1976).
} 
economists clearly have contributed to three specific and important antitrust accomplishments in recent decades: improved antitrust merger analysis, improved antitrust treatment of vertical mergers and vertical restraints, and improved understanding of predatory pricing. But there are still important advances and adaptations in antitrust policy to which economics and economists can surely contribute, so as to make competition policy an even better contributor to economic growth.

As is true in many other policy areas, the tasks of good competition policy economists are never finished. 


\section{$\underline{\text { References }}$}

Ackerman, Bruce A. and William T. Hassler. Clean Air and Dirty Coal. New Haven, Conn.: Yale University Press, 1981.

Adelman, Morris A., "The A \& P Case," American Economic Review, 39 (May 1949), pp. 280-283.

Adelman, Morris A., "Economic Aspects of the Bethlehem Opinion," Virginia Law Review, 45 (1959), pp. 684-696.

American Bar Association (ABA), "Report of the ABA Commission to Study the Federal Trade Commission," September 15, 1968; reprinted in Journal of Reprints for Antitrust Law and Economics, 1 (Winter 1969), pp. 885-1009.

Antitrust Modernization Commission (AMC), Report and Recommendations. Washington, D.C.: AMC, April 2007.

Areeda, Phillip E. and Herbert Hovenkamp, Fundamentals of Antitrust Law. New York: Aspen, 2004.

Areeda, Phillip E., Louis Kaplow, and Aaron S. Edlin, Antitrust Analysis: Problems, Text, Cases. New York: Aspen Publishers, 2004.

Barnett, Thomas O., "Competition Law and Policy Modernization: Lessons from the U.S. CommonLaw Experience," Presentation to the Lisbon Conference on Competition Law and Economics, Lisbon, Portugal, November 16, 2007; available at:

http://www.usdoj.gov/atr/public/speeches/227755.htm

Baumol, William J., "Reasonable Rules for Rate Regulation: Plausible Policies for an Imperfect World," in Almarin Phillips and Oliver E. Williamson, eds., Prices: Issues in Theory, Practice, and Public Policy. Philadelphia: University of Pennsylvania Press, 1968, pp. 101-123.

Baumol, William J., "Quasi-Permanence of Price Reductions: A Policy of Preventing Predatory Pricing," Yale Law Journal, 87 (November 1979), pp. 1-26.

Baumol, William J. and Alfred G. Walton, "Full Costing, Competition and Regulatory Practice," Yale Law Journal, 82 (March 1973), pp. 639-655.

Behrman, Jack N., "Japanese Industrial Policy: A View from Outside," in Robert E. Driscoll and Jack N. Behrman, eds., National Industrial Policies. Cambridge, Mass.: Oelgeschlager, Gunn \& Hain, 1984b, pp. 85-91.

Benston, George J., "Accounting Numbers and Economic Values," Antitrust Bulletin, 27 (Spring 
1982), pp. 161-215.

Bianchi, Patrizio and Sandrine Labory, eds., International Handbook on Industrial Policy. Cheltenham: Edward Elgar, 2006.

Bowman, Ward S., Jr., "The Prerequisites and Effects of Resale Price maintenance," University of Chicago Law Review, 22 (Summer 1955), pp. 825-873.

Bowman, Ward S., Jr., "Tying Arrangements and the Leverage Problem," Yale Law Journal, (November 1957), pp. 19-36.

Bowman, Ward S., Jr., Patent and Antitrust Law: A Legal and Economic Appraisal. Chicago: University of Chicago Press, 1973.

Brock, Gerald W., "Dominant Firm Response to Competitive Challenge: Peripheral Manufacturers' Suits against IBM (1979-1983)," in John E. Kwoka, Jr., and Lawrence J. White, eds., The Antitrust Revolution, New York: HarperCollins, 1989, pp. 160-182.

Brodley, Joseph F., Patrick Bolton, and Michael H. Riordon, "Predatory Pricing: Strategic Theory and Legal Policy," Georgetown Law Journal, 88 (August 2000), pp. 2239-2330.

Brodley, Joseph F. and George A. Hay, "Predatory Pricing: Competing Economic Theories and the Evolution of Legal Standards," Cornell Law Review, 66 (April 1981), pp. 738-803.

Buccirossi, Paolo, ed., Handbook of Antitrust. Cambridge, Mass.: MIT Press, 2007.

Burnett, William B., "Predation by a Nondominant Firm: The Liggett Case (1993)," in John E. Kwoka, Jr., and Lawrence J. White, eds., The Antitrust Revolution: Economics, Competition, and Policy, 3rd edn. New York: Oxford University Press, 1999, pp. 239-263.

Burstein, Meyer L., "The Economics of Tie-In Sales," Review of Economics and Statistics, 42 (February 1960a), pp. 68-73.

Burstein, Meyer L., "A Theory of Full-Line Forcing," Northwestern University Law Review, (March-April 1960b), pp. 62-95.

Cohen, Wesley M., "Empirical Studies of Innovative Activity," in Handbook of the Economics of Innovation and Technological Change, edited by Paul Stoneman. Cambridge, Mass.: Blackwell, 1995, pp. 182-264.

Cohen, Wesley M. and Richard C. Levin, "Empirical Studies of Innovation and Market Structure," in Handbook of Industrial Organization, Vol. 2, edited by Richard Schmalensee and Robert Willig. Amsterdam: North-Holland, 1989, pp. 1059-1107. 
De Jong, Henry W. and William G. Shepherd, eds., Pioneers of Industrial Organization: How the Economics of Competition and Monopoly Took Shape. Cheltenham: Edward Elgar, 2007.

DeLamarter, Richard T., Big Blue: IBM's Use and Abuse of Power. New York: Dodd, Mead, 1986.

Driscoll, Robert E. and Jack N. Behrman, "Introduction," in Robert E. Driscoll and Jack N. Behrman, eds., National Industrial Policies. Cambridge, Mass.: Oelgeschlager, Gunn \& Hain, 1984, pp. 1-24.

Edlin, Aaron S. and Joseph Farrell, "The American Airlines Case: A Chance to Clarify Predation Policy (2001)," in John E. Kwoka, Jr., and Lawrence J. White, eds., The Antitrust Revolution, 4th edn. New York: Oxford University Press, 2004, pp. 502-527.

Elzinga, Kenneth G., "Collusive Predation: Matsushita v. Zenith (1986)," in John E. Kwoka, Jr., and Lawrence J. White, eds., The Antitrust Revolution: Economics, Competition, and Policy, 3rd edn. New York: Oxford University Press, 1999, pp. 220-238.

Evans, David S., ed., Breaking up Bell: Essays on Industrial Organization and Regulation. New York: North Holland, 1983.

Federal Trade Commission, "FTC History: Bureau of Economics Contributions to Law Enforcement, Research, and Economic Knowledge and Policy," Roundtable with Former Directors of the Bureau of Economics, Federal Trade Commission, September 4, 2003; available at: http://www.ftc.gov/be/workshops/directorsconference/docs/directorstableGOOD.pdf

Fisher, Franklin M., "On the Mis-Use of the Profits-Sales Ratio to Infer Monopoly Power," RAND Journal of Economics, 18 (Autumn 1987), pp. 384-396.

Fisher, Franklin M. and John J. McGowan, "On the Misuse of Accounting Rates of Return to Infer Monopoly Profits," American Economic Review, 73 (March 1983), pp. 82-97.

Fisher, Franklin M., John J. McGowan, and Joen E. Greenwood, Folded, Spindled, and Mutilated: Economic Analysis and U.S. v. IBM. Cambridge, Mass.: MIT Press, 1983.

Green, Mark J., The Closed Enterprise System. New York: Grossman, 1972.

Harrington, Joseph E., Jr., "Corporate Leniency Programs and the Role of the Antitrust Authority in Detecting Collusion," working paper, Johns Hopkins University, February 2006; accessible at: http://www.econ.jhu.edu/People/Harrington/Tokyo.pdf

Houthakker, Hendrik S., "Expert Testimony by Economists: What Makes It Effective?" in Daniel J. Slottje, ed., The Role of the Academic Economist in Litigation Support. Amsterdam: Elsevier, 1999, 
pp. 1-10.

Hovenkamp, Herbert, Antitrust. St. Paul, Minn.: West Group, 1999a.

Hovenkamp, Herbert, Federal Antitrust Policy: The Law of Competition and its Practice. St. Paul, Minn.: West Group, 1999b.

Hovenkamp, Herbert, The Antitrust Enterprise: Principle and Execution. Cambridge, Mass.: Harvard University Press, 2005.

Johnson, Chalmers, MITI and the Japanese Miracle. Stanford, Calif.: Stanford University Press, 1982.

Johnson, Chalmers, ed., The Industrial Policy Debate. San Francisco: Institute for Contemporary Studies, 1984.

Joskow, Paul L. and Alvin K. Klevorick, "A Framework for Analyzing Predatory Pricing Policy," Yale Law Journal, 89 (December 1979), pp. 213-270.

Joskow, Paul L. and Roger G. Noll, "Economic Regulation: Deregulation and Regulatory Reform during the 1980s," in Martin Feldstein, ed., American Economic Policy in the 1980s. Chicago: University of Chicago Press, 1994, pp. 367-440.

Joskow, Paul L. and Nancy L. Rose, "The Effects of Economic Regulation," in Richard Schmalensee and Robert D. Willig, eds., Handbook of Industrial Organization, vol. 2. Amsterdam: North Holland, 1989, pp. 1449-1506.

Kaysen, Carl, United States v. United Shoe Machinery Corporation: An Economic Analysis of an Anti-Trust Case. Cambridge, Mass.: Harvard University Press, 1956.

Kaysen, Carl and Donald F. Turner, Antitrust Policy: An Economic and Legal Analysis. Cambridge, Mass.: Harvard University Press, 1959.

Kwoka, John E., Jr., and Lawrence J. White, eds., The Antitrust Revolution. Glenview, Ill.: Scott, Foresman, 1989.

Kwoka, John E., Jr., and Lawrence J. White, eds., The Antitrust Revolution: The Role of Economics, 2nd edn. New York: HarperCollins, 1994

Kwoka, John E., Jr., and Lawrence J. White, eds., The Antitrust Revolution: Economics, Competition, and Policy, 3rd edn. New York: Oxford University Press, 1999.

Kwoka, John E., Jr., and Lawrence J. White, eds., The Antitrust Revolution: Economics, 
Competition, and Policy, 4th edn. New York: Oxford University Press, 2004.

Kwoka, John E., Jr., and Lawrence J. White, eds., The Antitrust Revolution: Economics, Competition, and Policy, 5th edn. New York: Oxford University Press, 2009 (forthcoming).

King Robert G. and Ross Levine, "Finance and Growth: Schumpeter Might Be Right," Quarterly Journal of Economics, 108 (August 1993a), pp. 717-737.

King, Robert G. and Ross Levine, "Finance, Entrepreneurship, and Growth: Theory and Evidence," Journal of Monetary Economics, 32 (December 1993b), pp. 513-542.

Kovacic, William E., "The Influence of Economics on Antitrust," Economic Inquiry, 30 (April 1992), pp. 294-306.

La Porta, Rafael, Florencio Lopez-de-Silanes, Andre Schleifer, and Robert W. Vishny, "Legal Determinants of External Finance," Journal of Finance, 52 (July 1997), pp. 1131-50.

La Porta, Rafael, Florencio Lopez-de-Silanes, Andre Schleifer, and Robert W. Vishny, "Law and Finance," Journal of Political Economy, 106 (December 1998), pp. 1133-1155.

Lawrence, Robert Z., "Industrial Policy in the United States and Europe: Economic Principles and Political Practices," in Hiromichi Mutoh, Sueo Sekiguchi, Kotaro Suzumura, and Ippei Yamazawa, eds., Industrial Policies for Pacific Economic Growth. Boston: Allen \& Unwin, 1986, pp. 126-146.

Levine, Ross, "Financial Development and Economic Growth: Views and Agenda," Journal of Economic Literature, 35 (June 1997), pp. 688-726.

Levine, Ross, "The Legal Environment, Banks, and Long-Run Economic Growth, Journal of Money, Credit and Banking, 30 (August 1998), pp. 596-613.

Levine, Ross, "Law, Finance, and Economic Growth," Journal of Financial Intermediation, 8 (January/April 1999), pp. 8-35.

Marvel, Howard P., "Exclusive Dealing," Journal of Law \& Economics, 25 (April 1982, pp. 1-25.

Marvel, Howard P., "How Fair is Fair Trade?" Contemporary Policy Issues, 3 (Spring 1985), pp. $23-$ 36.

Marvel, Howard P. and Stephen McCafferty, "Resale Price Maintenance and Quality Certification," Rand Journal of Economics, 15 (Autumn 1984), pp. 346-359.

Marvel, Howard P. and Stephen McCafferty, "The Welfare Effects of Resale Price Maintenance," Journal of Law \& Economics, 28 (May 1985), pp. 363-379. 
Marvel, Howard P. and Stephen McCafferty, "The Political Economy of Resale Price Maintenance," Journal of Political Economy, 94 (October 1986), pp. 1074-1095.

McCraw, Thomas K., ed., America versus Japan. Boston: Harvard Business School Press, 1986.

McGee, John S., "Predatory Price Cutting: The Standard Oil (N.J.) Case," Journal of Law \& Economics, 1 (October 1958), pp. 137-169.

Mueller, Willard F., "The Revival of Economics at the FTC in the 1960s," Review of Industrial Organization, 25 (August 2004), pp. 91-105.

Nicholls, William H., "The Tobacco Case of 1946," American Economic Review, 39 (May 1949), pp. 284-296.

Nicols, Alfred, "The Cement Case," American Economic Review, 39 (May 1949), pp. 297-310.

Noll, Roger G., and Owen, Bruce M. "The Anticompetitive Uses of Regulation: United States v. AT\&T (1982)," in John E. Kwoka, Jr., and Lawrence J. White, eds., The Antitrust Revolution: The Role of Economics, 2nd edn. New York: HarperCollins, 1994, pp. 328-375.

Ordover, Janusz A. and Robert D. Willig, "An Economic Definition of Predation: Pricing and Product Innovation," Yale Law Journal, 91 (November 1981), pp. 8-53.

Ordover, Janusz A. and Robert D. Willig, "Access and Bundling in High-Technology Markets," in Jeffrey A. Eisenach and Thomas M. Lenard, eds., Competition, Innovation, and the Microsoft Monopoly: Antitrust in the Digital Marketplace. Boston: Kluwer, 1999, pp. 103-128.

Organization for Economic Development and Cooperation, Objectives and Instruments of Industrial Policy: A Comparative Study. Paris: OECD, 1975.

Peltzman, Sam, "Toward a More General Theory of Regulation," Journal of Law \& Economics, 19 (August 1976), 211-40.

Peltzman, Sam, "Aaron Director's Influence on Antitrust Policy," Journal of Law \& Economics, 48 (October 2005), pp. 313-330.

Peltzman, Sam, "George Joseph Stigler," in Henry W. de Jong and William G. Shepherd, eds., Pioneers of Industrial Organization: How the Economics of Competition and Monopoly Took Shape. Cheltenham: Edward Elgar, 2007, pp. 239-244.

Pitelis, Christos N., "Industrial Policy: Perspectives, Experience, Issues," in Patrizio Bianchi and Sandrine Labory, eds., International Handbook on Industrial Policy. Cheltenham: Edward Elgar, 
2006, pp. 435-449.

Posner, Richard A., "A Program for the Antitrust Division," University of Chicago Law Review, 38 (Spring 1971a), pp. 500-536.

Posner, Richard A., "Taxation by Regulation," Bell Journal of Economics and Management Science, 2 (Spring 1971b), pp. 22-50.

Posner, Richard A., "Theories of Economic Regulation," Bell Journal of Economics and Management Science, 5 (Autumn 1974), pp. 335-358.

Preston, Lee, "Territorial Restraints: GTE Sylvania (1977)," in John E. Kwoka, Jr., and Lawrence J. White, eds., The Antitrust Revolution: The Role of Economics, 2nd edn. New York: HarperCollins, pp. 311-327.

Roberts, Gary L., "The Use of Bundled Rebates by a Dominant Firm: LePage's v 3M," in John E. Kwoka, Jr., and Lawrence J. White, eds., The Antitrust Revolution, 5th edn. New York: Oxford University Press, 2009, forthcoming.

Scherer, F.M., "Predatory Pricing and the Sherman Act: A Comment," Harvard Law Review, 89 (March 1976), pp. 869-890.

Scherer, F.M., Innovation and Growth: Schumpeterian Perspectives. Cambridge, Mass.: MIT Press, 1984.

Scherer, F.M. and David Ross, Industrial Market Structure and Economic Performance. 3rd ed. Boston: Houghton-Mifflin, 1990.

Schumpeter, Joseph A. Capitalism, Socialism, and Democracy, 3rd edn. New York: Harper \& Brothers, 1950.

Shepherd, William G., "Edward S. Mason," in Henry W. de Jong and William G. Shepherd, eds., Pioneers of Industrial Organization: How the Economics of Competition and Monopoly Took Shape. Cheltenham: Edward Elgar, 2007, pp. 209-210.

Solow, Robert M., "Technical Change and the Aggregate Production Function," Review of Economics and Statistics, 39 (August 1957), pp. 312-320.

Solow, Robert M., "Growth Theory and After," American Economic Review, 78 (June 1988), pp. 307-317.

Stigler, George J. "A Theory of Oligopoly," Journal of Political Economy, 72 (February 1964), pp. 55-69. 
Stigler, George J., "The Dominant Firm and the Inverted Price Umbrella," Journal of Law \& Economics, 8 (October 1965), pp. 167-172.

Stigler, George, J., "The Theory of Regulation," Bell Journal of Economics and Management Science, 2 (Spring 1971), pp. 3-21.

Sullivan, E. Thomas and Herbert Hovenkamp, Antitrust Law, Policy and Procedure: Cases, Materials, Problems. Charlottesville, Va.: Lexis Publishing, 1999.

Sullivan, Lawrence A. and Warren S. Grimes, The Law of Antitrust: An Integrated Handbook. St. Paul, Minn.: Thomson/West, 2006.

Telser, Lester G. "Why Should Manufacturers Want Fair Trade?" Journal of Law \& Economics 3 (October 1960), pp. 86-105.

Telser, Lester G., "Cutthroat Competition and the Long Purse," Journal of Law \& Economics, 9 (October 1966), pp. 259-277.

Wachter, Michael L. and Susan M. Wachter, "Introduction," in Michael L. Wachter and Susan M. Wachter, eds., Toward a New Industrial Policy? Philadelphia: University of Pennsylvania Press, 1981, pp. 1-5.

Werden, Gregory J., "The 1982 Merger Guidelines and the Ascent of the Hypothetical Monopolist Paradigm," Antitrust Law Journal 71 (2003), pp. 253-276.

Werden, Gregory J., "Identifying Exclusionary Conduct under Section 2: The 'No Economic Sense Test,"' Antitrust Law Journal, 73 (No. 2, 2006), pp. 413-434.

White, Lawrence J., "The Revolution in Antitrust Analysis of Vertical Relationships: How Did We Get from There to Here?" in Robert J. Larner and James W. Meehan, eds., Economics and Antitrust Policy. New York: Quorum, 1989, pp. 103-121.

White, Lawrence J., "Antitrust Activities during the Clinton Administration," in Robert W. Hahn, ed., High Stakes Antitrust: The Last Hurrah? Washington, D.C.: Brookings, 2003, pp. 11-44.

White, Lawrence J., "Horizontal Antitrust Merger Enforcement: Some Historical Perspectives, Some Current Observations," prepared for the Antitrust Modernization Commission's Economists' Roundtable on Merger Enforcement, January 19, 2006; Working Paper \#EC-06-01, Stern School of Business, New York University; available at:

http://www.stern.nyu.edu/eco/wkpapers/merger_enforcement.pdf

White, Lawrence J., "Antitrust Policy and Industrial Policy: A View from the U.S.," Working Paper 
\#EC-08-02, Stern School of Business, New York University, 2008a; accessible at:

http://w4.stern.nyu.edu/emplibrary/antitrust\%20\&\%20industrial\%20policy.ljw\%20revision.1-14-

08[1].pdf

White, Lawrence J., "The Growing Influence of Economics and Economists on Antitrust: An Extended Discussion," Working Paper \#EC-08-03, Stern School of Business, New York University, 2008b; accessible at:

http://w4.stern.nyu.edu/emplibrary/economics\%20\&\%20antitrust.corrected\%20draft.pdf

White, Lawrence J., "Market Power and Market Definition in Monopolization Cases: A Paradigm is Missing," in Wayne D. Collins, ed., Issues in Competition Law and Policy. Chicago: American Bar Association, 2008c.

Williamson, Oliver E., "Economies as an Antitrust Defense: The Welfare Tradeoffs." American Economic Review, 58 (March 1968), pp. 18-36.

Williamson, Oliver E., "Predatory Pricing: A Strategic and Welfare Analysis," $\underline{\text { Yale Law Journal, } 87}$ (December 1977), pp. 284-340.

Williamson, Oliver E., "Economics and Antitrust Enforcement: Transition Years," Antitrust, 17 (Spring 2003), pp. 61-65.

Wils, Wouter P.J., "Leniency in Antitrust Enforcement: Theory and Practice," World Competition, 30 (March 2007), pp. 25-63.

Winston, Clifford, "Economic Deregulation: Days of Reckoning for Microeconomists," Journal of Economic Literature, 31 (September 1993), pp. 1263-1289.

Winston, Clifford, "U.S. Industry Adjustment to Economic Deregulation," Journal of Economic Perspectives, 12 (Summer 1998), pp. 89-110. 